https://doi.org/10.48009/1_iis_2007_37-43

\title{
ENHANCING INTERACTION IN ASYNCHRONOUS ONLINE INFORMATION SYSTEMS EDUCATION
}

\author{
John Girard, Minot State University, john.girard@minotstateu.edu \\ Lori Willoughby, Minot State University, lori.willoughby@minotstateu.edu \\ Kristi Berg, Minot State University, kristi.berg@minotstateu.edu
}

\begin{abstract}
Will increasing the level of interaction help students or is it just another time consuming task for already busy students? According to Karen Swan [7] one may increase learning effectiveness through interaction in four general ways: interaction with content; interaction with instructors; interaction with classmates; and interaction with course interface.

The aim of this paper is to consider how one may enhance interaction with instructors and classmates through the use of virtual collaboration, voice, and video. Virtual collaboration provides the students the ability to meet course, individual, and team goals; create class and team learning communities; collaborate on document development; and successfully complete team projects. Voice feedback enhances interaction and facilitates timely feedback, often a missing component in asynchronous education. A properly produced video motivates students and focuses their energy through engagement and excitement.
\end{abstract}

Our research indicates virtual collaboration, voice, and video provides an unprecedented level of interaction in asynchronous online IS education. This paper chronicles the lessons learned from an innovative Great Plains university.

Keywords: Online education, interaction, asynchronous, engagement

\section{INTRODUCTION}

More often than not online educators are divided into two distinct groups: those supporting asynchronous online education and those supporting synchronous online education. Invariably the two groups seem to be at odds, each arguing, very emotionally, the merits of their preferred mode, usually to the exclusion of the other mode. But what would happen if you could marry the best of both worlds? Surely an ideal state would be one in which high fidelity communication is possible in a time-free environment.

Before debating the merit of each of these types of online education it may be worth defining the terms. According to a recent Sloan Consortium report entitled Growing by Degrees, which surveyed more than 1000 colleges and universities in the United States, "there is a great deal of diversity among course delivery methods used by individual instructors"[1]. In the report they segment the various types and define Online Courses as those with $80+\%$ of the content delivered online and typically without face-to-face meetings - we will use this as the basis for our discussions of online courses. Many definitions exist; however, for this paper the following definitions seem appropriate [2]:

"Synchronous Online Education - Internet based education where the instructor and students participate in learning activities at the same time.

Asynchronous Online Education - Internet based education where the instructor and students participate in learning activities at different times.”

Although the two types of online education appear similar in nature, there is a single differentiating feature, the timing of the learning activities. By definitions synchronous means the same time compared to asynchronous which means different times. According to Dr Robin Mason from the United Kingdom's Open University, there are four advantages to asynchronous delivery: flexibility, time to reflect, situated learning, and cost effective technology (1998). Three of the four are described in Table 1, the fourth (cost effective technology) does not apply to this paper as we will assume that a single learning management system is used within an institution and therefore the issue of cost effectiveness is not germane 
Table 1. Advantages of Asynchronous Online Education

\begin{tabular}{|l|l|}
\hline \multicolumn{1}{|c|}{ Trait } & \multicolumn{1}{c|}{ Mason's Description } \\
\hline Flexibility & $\begin{array}{l}\text { Access to the teaching material (e.g. } \\
\text { on the Web, or computer conference } \\
\text { discussions) can take place at any } \\
\text { time (24 hours of the day, 7 days a } \\
\text { week) and from many locations (e.g. } \\
\text { oil rigs) }\end{array}$ \\
\hline $\begin{array}{l}\text { Time to } \\
\text { reflect }\end{array}$ & $\begin{array}{l}\text { Rather than having to react 'on one's } \\
\text { feet', asynchronous systems allow the } \\
\text { learner time to mull over ideas, check } \\
\text { references, refer back to previous } \\
\text { messages and take any amount of } \\
\text { time to prepare a comment }\end{array}$ \\
\hline Situated \\
learning & $\begin{array}{l}\text { Because the technology allows } \\
\text { access from home and work, the } \\
\text { learner can easily integrate the ideas } \\
\text { being discussed on the course with } \\
\text { the working environment, or access } \\
\text { resources on the Internet as required } \\
\text { on the job. }\end{array}$ \\
\hline
\end{tabular}

Most seasoned online educators would agree that each of these characteristics add value to education. However, Mason reminds us that synchronous delivery also has advantages as shown Table 2:

Table 2. Advantages of Synchronous Online Education

\begin{tabular}{|l|l|}
\hline \multicolumn{1}{|c|}{ Trait } & \multicolumn{1}{|c|}{ Mason's Description } \\
\hline Motivation & $\begin{array}{l}\text { Synchronous systems focus the } \\
\text { energy of the group, providing } \\
\text { motivation to distance learners } \\
\text { to keep up with their peers and } \\
\text { continue with their studies }\end{array}$ \\
\hline Telepresence & $\begin{array}{l}\text { Real time interaction with its } \\
\text { opportunity to convey tone and } \\
\text { nuance helps to develop group } \\
\text { cohesion and the sense of being } \\
\text { part of a learning community }\end{array}$ \\
\hline Good feedback & $\begin{array}{l}\text { Synchronous systems provide } \\
\text { quick feedback on ideas and } \\
\text { support consensus and decision } \\
\text { making in group activities, both } \\
\text { of which enliven distance } \\
\text { education }\end{array}$ \\
\hline Pacing & $\begin{array}{l}\text { Synchronous events encourage } \\
\text { students to keep up-to-date } \\
\text { with the course and provide a } \\
\text { discipline to learning which }\end{array}$ \\
\hline
\end{tabular}

Volume VIII, No. 1, 2007

\begin{tabular}{|l|l|}
\hline & $\begin{array}{l}\text { helps people to prioritise their } \\
\text { studies. }\end{array}$ \\
\hline
\end{tabular}

The aim of this paper is to consider how one may replicate the desired features of the synchronous environment in the asynchronous domain. In other words, is it possible for a student to benefit from the features of participating in learning activities at the same time while they actually participate in learning activities at different times? With a view to answering this question, a review of three proven techniques for enhancing the interaction within asynchronous online education follows.

As you read this paper, remember that our focus is online education. This caveat is noteworthy as the principles and practices to be discussed may not enhance classroom based classes. Although many of the issues may also be relevant to other styles of courses, it is important to realize that each mode of education demands different considerations.

You should also be aware that this paper intentionally focuses on the practical application of ideas not the theoretical side of things. Presented are the ideas that worked for us, notwithstanding what the literature may suggest. All too often we academics focus on what should work, in theory, and not what really works, in practice.

Perhaps the real question is Does interaction really matter? Will increasing the level of interaction help students or is it just another time consuming task for already busy students? According to Karen Swan [6] one may increase learning effectiveness through interaction in three general ways; in this paper we will focus on the first two:

- Interaction with Instructors

- Interaction with Peers

- Interaction with Content

Possibly the most significant characteristic of the techniques that follow is that they offer this enhanced interaction without the constraints typically associated with synchronous education. This important point should not be underestimated as many online students are working adults with many competing interests such as families, work, or community involvement. Add to this the results of a recent survey in which $64 \%$ of respondents agreed with the statement "Students need more discipline to succeed in an online course than in a face-to-face course"[1]. The result is a very busy group of 
students who must be very disciplined. This is further compounded by the challenges of students in different time zones and it quickly becomes apparent that the demands of synchronous online courses simply do not work for them.

\section{INTERACTION WITH INSTRUCTORS}

One way to emulate the interaction of face-to-face teaching is to add videos to courses. Video support enhances online education by engaging and exciting students - once students are engaged and excited about online education it is less likely they will become distracted or even worse drop the course! This time-tested technique is enjoyed by most students as they feel they are able to get connected with you. That said there are a few issues to consider before you grab your camera and begin producing your award winning documentary. The three key elements that must be considered are quality, accessibility, and technology [2].

Returning to Mason's four traits of synchronous online education video has the potential to add tremendous value to the learning experience. A properly produced video will certainly motivate students and focus their energy through engagement and excitement. Students respond very well to high quality videos because it helps them understand difficult material. They have the opportunity to replay the video several times to ensure they have mastered a particular concept. Arguably this is better than a synchronous video stream as students may pause, fast forward and rewind as they wish.

Videos are an excellent vehicle to create the telepresence to which Mason referred. Specifically the videos support virtual interaction and permit the instructor to "convey tone and nuance helps to develop group cohesion and the sense of being part of a learning community” as Mason described it. Once again one might argue that this presence is even more dominant than synchronous streams as we are able to ensure the quality. Often streaming video is degraded by poor network connections, which causes annoying and disruptive buffering. Nothing eliminates the value of presence more than dead air.

Mason argues that synchronous online education affords a pacing quality because "events encourage students to keep up-to-date with the course and provide a discipline to learning which helps people to prioritize their studies." This same impact may be achieved with videos. In fact that is precisely the reason for a series of short videos rather than one or more longer videos. Short videos, especially those that tease or temp the students with the next subject area, are particularly effective at enticing students to finish one module so that they can see what's next.

\section{Video iPod Trial}

A recent pilot project reinforced these findings. The aim of the pilot was to determine if a hand-held device could enhance the educational experience of online graduate students studying MIS. The course was designed so that all course content was available on fourth generation Apple iPod (commonly referred to as a Video iPod). The content included:

- Video lessons for each module (produced by the instructor)

- Audio textbook (commercially available)

- Video management case scenarios

(commercially available)

- Video podcasts (commercially available)

- Audio podcasts (commercially available)

- Audio assignment feedback (produced by the instructor)

The results of trial, Table 3, were:

Table 3. Pilot Project Findings

\begin{tabular}{|l|l|l|}
\hline \multicolumn{1}{|c|}{ Question } & \multicolumn{1}{|c|}{ Results } & \multicolumn{1}{c|}{ Selective Qualitative Comments } \\
\hline $\begin{array}{l}\text { Did the addition of this } \\
\text { technology to the course, } \\
\text { help you to understand } \\
\text { the course material? }\end{array}$ & $\begin{array}{l}\text { Yes: } 83.3 \% \\
\text { No: } 16.7 \%\end{array}$ & $\begin{array}{l}\text { The textbook on the iPod helps me to "read" during my 30 minute } \\
\text { commute. Now, instead of reading for an hour when I get home, I } \\
\text { can use that time to do further research for the class. Also, the } \\
\text { audio and videos are better at explaining the material than reading } \\
\text { alone. This is especially important in an online course where there } \\
\text { is less communication with the instructor and classmates. }\end{array}$ \\
& $\begin{array}{l}\text { The addition of the videos and the podcast definitely helped in } \\
\text { understanding the material. In addition, the "video cases" allowed } \\
\text { me to understand the case better, seeing the non-verbals from the } \\
\text { participants was better than reading the case only. }\end{array}$ \\
\hline
\end{tabular}




\begin{tabular}{|c|c|c|}
\hline Question & Results & Selective Qualitative Comments \\
\hline $\begin{array}{l}\text { The files in this course } \\
\text { had audio and visual } \\
\text { components. Do you } \\
\text { think the same learning } \\
\text { result could have been } \\
\text { achieved with an audio- } \\
\text { only component? }\end{array}$ & $\begin{array}{l}\text { Yes: } 33.3 \% \\
\text { No: } 66.7 \%\end{array}$ & $\begin{array}{l}\text { The audio textbook was effective, but the videos of case studies and } \\
\text { instructor better explain the material in real world examples. } \\
\text { As a visual learner, an "audio" only course would have made it } \\
\text { much more difficult. } \\
\text { I like the video because it is entertaining and more classroom like. }\end{array}$ \\
\hline $\begin{array}{l}\text { Did the addition of this } \\
\text { technology to the course, } \\
\text { help you to complete } \\
\text { course assignments? }\end{array}$ & $\begin{array}{l}\text { Yes: } 100 \% \\
\text { No: } 0 \%\end{array}$ & $\begin{array}{l}\text { The ability to download the entire course into the ipod has helped, } \\
\text { so far, in the course assignments. I didn't need to remember to print } \\
\text { assignments, etc. The entire course was on the ipod, very } \\
\text { convenient. } \\
\text { I was able to take the ipod on airplanes and airports, in the car and } \\
\text { places where internet was not available. } \\
\text { It was nice to have access to the material at all times, no matter } \\
\text { where you were. }\end{array}$ \\
\hline $\begin{array}{l}\text { Did you use the } \\
\text { electronic textbook } \\
\text { available for this course? }\end{array}$ & $\begin{array}{l}\text { Yes: } 100 \% \\
\text { No: } 0 \%\end{array}$ & \\
\hline $\begin{array}{l}\text { Do you feel that adding } \\
\text { this technology improved } \\
\text { your learning in this } \\
\text { course? }\end{array}$ & $\begin{array}{l}\text { Yes: } 66.7 \% \\
\text { No: } 33.3 \%\end{array}$ & \\
\hline $\begin{array}{l}\text { Did you experience } \\
\text { technical difficulties } \\
\text { when using the iPod? }\end{array}$ & $\begin{array}{l}\text { Yes: } 33.3 \% \\
\text { No: } 67.7 \%\end{array}$ & $\begin{array}{l}\text { Initially I had trouble getting the audiobook to the iPod. This was } \\
\text { resolved quickly } \\
\text { Could not get my book to download onto the ipod right away. }\end{array}$ \\
\hline $\begin{array}{l}\text { Did the portability of the } \\
\text { iPod enhance your } \\
\text { experience in this } \\
\text { course? In other words, } \\
\text { did you find that being } \\
\text { able to access files from } \\
\text { your iPod was of value to } \\
\text { your educational } \\
\text { experience? }\end{array}$ & $\begin{array}{l}\text { Yes: } 83.3 \% \\
\text { No: } 16.7 \%\end{array}$ & $\begin{array}{l}\text { The portability was the strongest positive about the iPod use. I was } \\
\text { able to listen during my commute as well as repeat portions as } \\
\text { wanted. } \\
\text { Although it would have been more beneficial if I was always on the } \\
\text { move (traveling for work, etc), it was easier to bring along the ipod } \\
\text { than a briefcase full of course materials. For example, I had a } \\
\text { meeting in XXXX at the beginning of this semester. I was able to } \\
\text { listen to the audio book as during the trip, something I wouldn't } \\
\text { have been able to do with traditional course materials. While I was } \\
\text { there I had car trouble that took a day to fix, during this time I had } \\
\text { everything I needed to keep up on the course without any hassle. } \\
\text { Because of the additional availability of the material, in places, } \\
\text { where internet was not available, I have been able to have } \\
\text { continuous input from the class material. } \\
\text { I cannot really say that the Ipod enhanced my experience, but if I } \\
\text { was truly on the road much of the time I believe this would be a } \\
\text { great benefit. }\end{array}$ \\
\hline
\end{tabular}

A word of warning is in order as resource limitations restricted this pilot to just six students. With such a small sample one must be very careful how the findings are generalized. Notwithstanding the statistical implications, it seems prudent to highlight a few particular lessons: 
- $100 \%$ of students believed that the addition of this technology to the course, helped them complete course assignments.

- $83.3 \%$ of respondent stated that the technology helped them understand course material and that portability enhance their experience.

- $33.3 \%$ reported experiencing technological difficulties.

\section{INTERACTION WITH CLASSMATES}

Through virtual collaboration it is possible to enhance inaction with classmates and thereby improving the dynamic impact of an online class. Collaboration in the traditional classroom-based course happens seamlessly through instructor led discussions, side discussions by students, or casually outside of the classroom. Unbeknown to the students they are creating learning communities that enhance their learning, motivate them to complete the course, and learn independent of the professor. This collaboration creates a bond between the students and the professor. Once that bond is created a shared understanding of the course expectations begins to develop. The challenge of any online professor is to develop that same depth of collaboration into the asynchronous environment.

\section{Discussion Boards}

Typically students enrolled in online courses feel that they are alone in the learning process and do not expect to be part of a learning community. It is important for the professor to dispel that belief at the beginning of the class. In the classroom-based course we begin every course by introducing ourselves and then asking the students to do the same. We need to do the same in the online class. One of the easiest ways to begin the collaboration within the class is through the use of a discussion board.

Discussion boards can be used to create cohesiveness with the entire class. For example, at the beginning of every class we post an opening discussion introducing our self to the class telling a bit about our self and inviting the students to do the same. Before long students are responding to each post and beginning to learn about the members of the class. This is a great start to creating a learning community within the entire class. Once the students feel that they are part of a learning community they will find it much easier to communicate and to build team cohesiveness and trust.
Swan [7] recommends awarding a significant percentage of the overall course grade for participation in online discussions, a proposition that we support. This ensures that all students participate in the discussions and understand that this is not just busy work. Swan reminds us that to increase learning effectiveness one should "develop grading rubrics for discussion participation that reward desired cognitive behaviors" [7]. She adds that one may also increase learning effectiveness by encouraging vicarious interaction.

\section{Team Projects}

Collaborating as a class is a good start to ensure the creation of a successful learning community. This cohesiveness now needs to transcend to small teams within the class. Team projects are a vital component of many of our classes as they provide another opportunity for creating learning communities, albeit on a smaller scale. Each of the team learning spaces should have the same features as the course learning space. It is essential that the teams have these tools to collaborate effectively and work productively.

Collaborating effectively as part of a small team without the direction of the professor can create new challenges. The first challenge is in the formation of the team, which typically is formed in two ways; instructor choice or self selection. Despite the selection method, it is most important that the team spend some time getting to know each other. This is an opportunity for the team to create their social community. It is important that the teams understand the work schedules, family commitments, etc. of each member. This social understanding will assist the team in knowing that its members share a common understanding of the course, commitment to the course, and the team project.

Once the team has defined their social space and are ready to collaborate they will begin to determine how they will use the tools to assist in their virtual collaboration. It is important to remember that each team consists of unique individuals and that uniqueness will blend together to form a cohesive team with common goals. You may find that one team uses the discussion board extensively and another team uses email. It is not the tool that is important, rather the collaboration. So, give the students the freedom to choose what works for them.

After the teams have been determined and the team dynamics have been established the real learning begins. We have noticed that the students begin to 
take an active role in their learning by creating their own discussion topics and providing and giving feedback. Almost certainly you will note our repeated and very conscious use of the collective noun team instead of group. To us this is much more than semantics and we encourage you to use the term team. Teams are a very unique type of group in that they establish a common goal. This unites the individual members to achieve the collective objective. Alternatively groups are simply a gaggle of individuals that lack the common purpose. Snowden reminds us that "knowledge can only be volunteered; it cannot be conscripted" [5] We promote a collective environment of trust, an environment in which team members feel a need to contribute and share knowledge.

Despite our best efforts to create this atmosphere of trust, sharing, and learning we recognize that occasionally students will seek a free ride by becoming a social loafer. Piezon \& Donaldson [4] recommend a number of tools and techniques to reduce the likelihood of social loafing, including the use of peer evaluations, reducing the team sizes, emphasizing the importance of teamwork, and the use the meaningful and immediate feedback.

\section{Collaborative Workspaces}

Another aspect to virtual collaboration is team workspaces, which facilitate work on team or individual tasks at the convenience of the members. The workspace should be a branch from the class site and should provide the ability to store documents in a common work space, receive notification when a task or document has been added or modified, and a secure area from other teams.

Providing a separate storage area for each team is critical in forming the confidence to virtually collaborate on documents. It is important that you provide instructions on how to name the document, check out the document for editing, saving back to the common space, checking the document back in, and creating a version history. We have also found it important to include instruction on how to use the collaboration tools specific to each application tool. It is also important to track the process of the document development from draft to ready for review to final. This document property will provide a sense of movement through the team project and provide a sense of completion for each phase of the project.

We have found that online students are not unlike the on-ground students in that they want a sense of security when sharing their documents with members of the class not in their team. Both groups of students want to develop their ideas without the fear of being copied. The collaborative workspace you choose must provide this type of security. Most collaborative workspaces can provide broad access to the course site while allowing select access to other areas.

Most collaborative workspaces also provide the team the ability to store contact information for each member, create surveys, and search for specific documents. We have found that the use of these features depends on the dynamics of the team and the detail required in successfully completing the team project. It is our belief that virtual collaboration satisfies all four of Mason's synchronous delivery traits, motivation, telepresence, feedback, and pacing. Virtual collaboration provides the students the ability to meet the course and individual team goals, create class and team learning communities, collaborate on document development, and successfully complete the team project.

\section{SUMMARY}

The aim of this paper was to answer the question Is it possible to deliver asynchronous courses with the advantages typically associated with synchronous courses? With a view to answering this question, we reviewed three techniques that may be utilized within asynchronous online education: Video, Voice, and Virtual Collaboration. Each of the three tools reviewed increase the students' interaction with content, instructors, classmates and course interfaces. Together this interaction leads to higher levels of learning effectiveness.

\section{REFERENCES}

1. Allen, I., \& Seamn, J. (2005). Growing by Degrees: Online Education in the United States, 2005: The Sloan Consortium.

2. Girard, J. P., Willoughby, L., \& Berg, K. (2006). Video, voice, and virtual collaboration: The 3V's of asynchronous education. In N. A. Buzzetto-More (Ed.), Principles of Effective Online Teaching: A Handbook for Educators Developing E-Learning. Santa Rosa, California: Informing Science Press.

3. Mason, R., (1998) Globalising education: Trends and applications. London; New York: Routledge.

4. Piezon, S. L., \& Donaldson, R. L. (2005). Online groups and social loafing: Understanding 
student-group interactions. Online Journal of

Distance Learning Administration 8(4).

5. Snowden, D. (2002). Complex acts of knowing:

Paradox and descriptive self-awareness. Journal

of Knowledge Management, 6(2), 100.

6. Swan, K. (2004). Learning online: current research on issues of interface, teaching presence and learner characteristics. In J. Bourne \& J. C. Moore (Eds.), Elements of Quality Online Education, Into the Mainstream (pp. 63-70). Needham, MA: Sloan Center for Online Education.

7. Swan, K. (2004). Relationships between interactions and learning in online environments: The Sloan Consortium. 